\title{
Plant-Mediated Iron Nanoparticles and their Applications as Adsorbents for Water Treatment-A Review
}

\author{
Segun Michael Abegunde ${ }^{\mathrm{a}, *}$, Kayode Solomon Idowu ${ }^{\text {a }}$, Ayodele Omoniyi Sulaimon ${ }^{\mathrm{b}}$ \\ ${ }^{a}$ Department of Science Technology, Federal Polytechnic, Ado-Ekiti, Nigeria \\ ${ }^{b}$ Department of Agricultural Technology, Federal Polytechnic, Ado-Ekiti, Nigeria
}

\begin{abstract}
Receive Date: 08 December 2019, Revise Date: 29 January 2020, Accept Date: 06 February 2020
Abstract:

Plant-mediated synthesis of iron oxide nanoparticles has been increasingly drawing attention due to its ecofriendly nature and cost effectiveness. The biosynthesis technique engages plant secondary metabolites such as alkaloids, flavonoids, saponins, phenols, proteins, carbohydrates, glycosides, quinine, steroids, and tannins as reducers and/or stabilizers in the process of forming nanoparticles thereby replacing hazardous chemicals known with physical and chemical methods of nanomaterial synthesis. Biosynthesis method of nano particles has helped to a great extent to overcome some drawbacks, such as high energy and space requirement as well as high cost and hazard associated with various known physical and chemical methods. This work reviewed the biosynthesis of plant mediated iron oxide nanoparticles and their applications in water and wastewater treatment. Much work has been done to explore the effective, safe and cheap method for the dye removal in recent years. However, in future, more methods need to be explored to study and check the removal of dyes from wastewater using plant-mediated iron oxide nanoparticles for safer, cheaper and more efficient performance.
\end{abstract}

DOI: $10.33945 /$ SAMI/JCR.2020.2.3

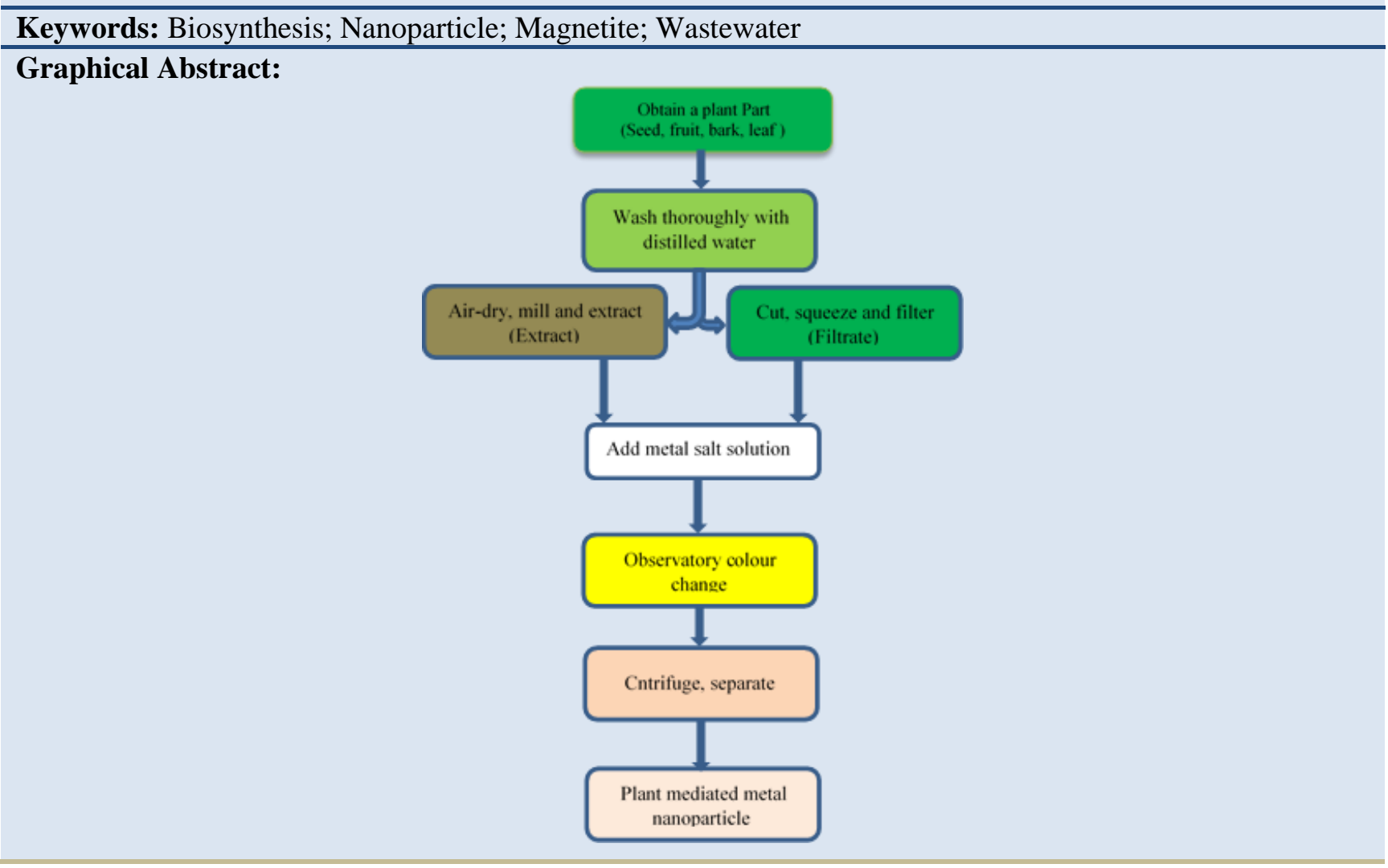

*Corresponding author: Segun Michael Abegunde, Email: abegunges@gmail.com 


\section{Biography:}
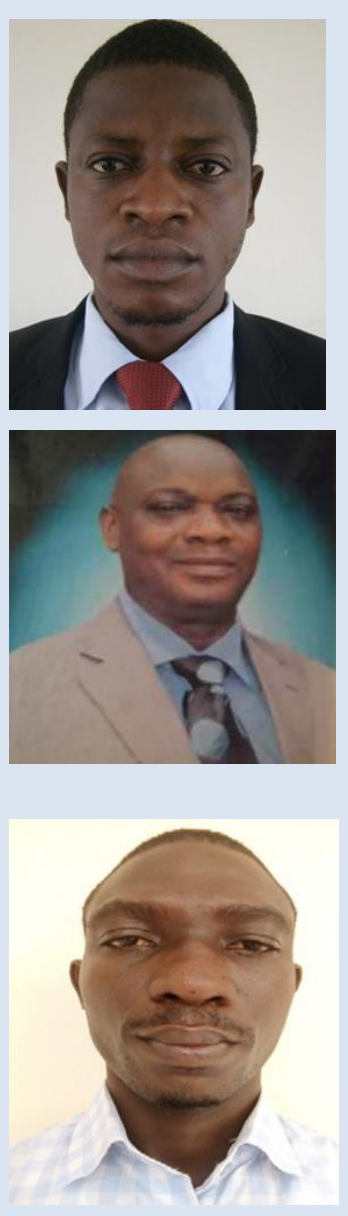

Segun Michael Abegunde: He obtained his HND in Applied Chemistry from the Federal polytechnic, Ado-Ekiti in 2009, B.Sc degree from Joseph Ayo Babalola University, Arakeji in 2017, and obtained M.Tech in chemistry in 2019 from Federal University of Technology, Akure. Presently, he is working with Federal polytechnic, Ado-Ekiti in the department of Science technology (Applied chemistry option). His research interests focus on nanotechnology, adsorption, corrosion and water decontamination.

Kayode Solomon Idowu: He obtained his B.Sc degree in Biochemistry from the University of Ibadan and his MSc (Biochemistry) from Joseph Ayo Babalola University, Arakeji. Presently, he is working in the department of science technology, Federal Polytechnic, Ado-Ekiti. His research interest is in drug metabolism.

Ayodele Omoniyi Sulaimon: He obtained his B.Sc degree in Zoology in 2010 from the university of Ado-Ekiti now Ekiti State University. He proceeded for his M.Sc in Ecology \& Environmental Biology and presently pursuing his $\mathrm{PhD}$ in the same university. He works as a lecturer at the department of Agricultural Technology, Federal polytechnic, Ado-Ekiti. He has trained quite a number of students in skill acquisition in Apiculture.

\section{Introduction}

Over the years, aquatic communities have been extensively suffered due to rapid industrialization and this calls for a global concern. Textile, paper, paint, and printing industries are undeniable and the major sources of environmental pollution. Textile industries consume a lot of dye and generate large amounts of wastewater, containing both organic and inorganic pollutants. It is reported that about $15 \%$ of 700,000 metric tonnes of over 10,000 commercially available dyes produced yearly are lost in textile effluents during production and processing operation [1-4]. The discharged wastewater in water bodies poses a potential risk to aquatic environment due to the bioaccumulation [4]. Generally, the presence of metal ions, aromatic ring, and halogen groups in dye molecules increases their toxicity, genotoxicity, mutagenic, carcinogenicity, and teratogenic property to living organisms [5-7]. Accumulation of dye in water bodies affects water turbidity, chemical oxygen demand and prevents light penetration through water. This disturbs photosynthesis to a large extent [8-12] and poses a great danger to aquatic animals and plants; therefore there is neced for the dye removal before being discharged. The needs for environmental sustainability had led many researchers in the development of several techniques for pollutant removal from wastewater. The techniques include the Fenton process [13]; degradation by photocatalytic processes [14-19], sono-chemical degradation [20]; photo-Fenton processes [21], chemical coagulation/flocculation, cloud point extraction, ozonation, oxidation, chemical precipitation, nanofiltration, ion exchange, reverse osmosis, and ultrafiltration[22-26], and modified methods such as those combining ultrasound with adsorption-desorption processes[27-30]. These methods proved to be effective; however, some revealed some limitations in the areas such as high cost of operation, a bulk of chemicals required, and disposal problems due to the accumulation of the bulk of sludge [17, 31-34]. Among these techniques, adsorption is considered as one of the most efficient mothod for wastewater treatment due to its design and operation simplicity, non-toxic, low cost of adsorbent and high efficiency $[3,34]$. Adsorption is the deposition of molecular species (atoms, ions or molecules) from a gas, liquid or dissolved solid onto the surface of a solid [35]. The method has been in existence from the early days of the decolorization of sugar solutions by bone char, to the later adoption of activated carbon for nerve gas removal from the battlefield, to today's several applications in various 
fields. The adsorption method has been found as a useful tool in purification and separation processes. Adsorption techniques employ porous materials with large surface area, suitable surface charges, moderate mechanical strength and chemical interaction. Materials such as silica gel, clay, alumina, activated carbon, molecular sieve zeolites, synthetic resins, impregnated biomaterials, with the latest being nanoparticles have been extensively used as adsorbents for industrial applications in water and wastewater purifications.

Nanotechnology refers to a science engaging in the creation and applications of materials whose particles exist within the nanoscale; and, by convention, be between 1 and $100 \mathrm{~nm}$ in size [36]. Over the last few decades, nanotechnology has been a flourishing field of technology, creating novel ways of synthesizing particles of unique features and great importance. Nanotechnology provides the opportunities to manipulate the materials' properties by controlling their sizes and shapes, which have been the reason for numerous potential applications of nanomaterials. Nanomaterials have unique properties that distinguish them from a number of bulk materials, these include high surface energy, the large fraction of surface atoms, spatial confinement, and reduced imperfections [37]. Nanoscience is an important growing field with diverse applications in science and technology: environmental sustainability, medicine, food, drug, catalysis, material, energy, agriculture, telecommunication, among others $[37,38]$. For these purposes, different nanoparticles are available in different material sizes, shapes, morphologies, compositions, physical and chemical properties. The notably ones include carbon-based nanoparticles, metal nanoparticles, ceramic nanoparticles, semiconductor nanoparticles, lipidbased nanoparticles and polymeric nanoparticles. Among the nanoparticles commonly employed for the purposes mentioned earlier, the metallic nanoparticles have attracted a great deal of attention due to their remarkable properties including, mechanical strengths, thermal strength, high surface area, high ordered structure, magnetic properties, and optical properties [39]. Metal nanoparticles can generally be described as submicron scale entities consists of pure metals or their compounds [40]. The metallic nanoparticles are zerodimension nanosized metals ranging between $1 \mathrm{~nm}$ and $100 \mathrm{~nm}$ [36]. Metallic nanoparticles are characterized by small size and large surface area. Their size, shape, and surface charge all influence their cellular uptake; hence the attributes for their wide applications and demand.

\section{Synthesis of Bio Nanoparticles Using Plant Materials}

Recently, scientists have found it economical to synthesize bio-nanoparticles from plants, fungus and algae as they are cost-effective, safe, efficient, and readily available. In achieving this feat, researchers have explored different techniques in developing nanomaterials. The techniques of producing nanoparticles can generally be classified as either top down approach or a bottom up approach. In the top down approach, nanoparticles are synthesized by size reduction from a suitable starting material [41]. This size reduction can be achieved through various physical and chemical manipulations. In a bottom up method of nano development, particles are built from smaller entities [42]. In a bottom up nano particle synthesizing method, the building blocks of the nanoparticles are first produced and then assembled to give the final desired product [43]. However, these methods, physical and chemical methods, can generally be considered to be expensive and unsafe due to the need for special equipment, high energy and chemical substances that are flammable, toxic and corrosive [44].

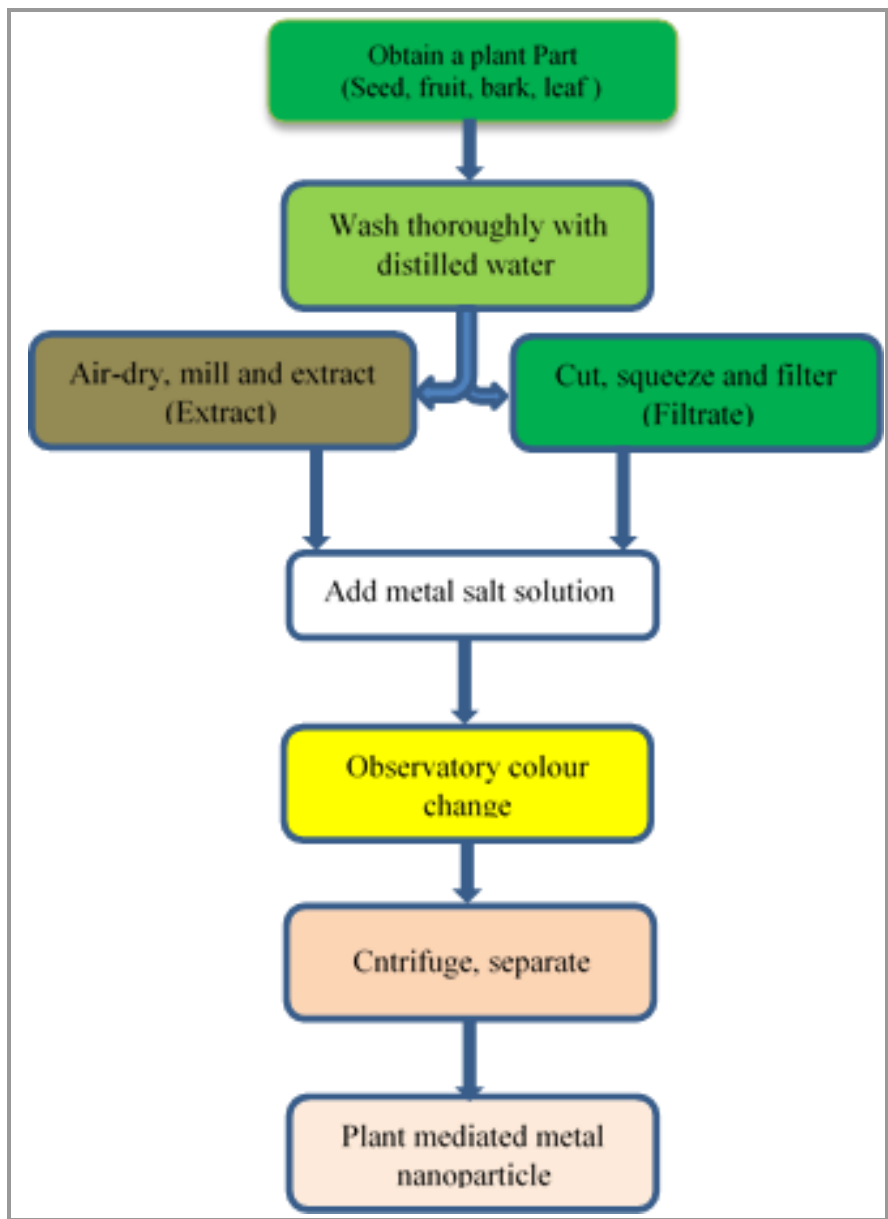

Figure 1. Schematic protocol for green synthesis of plant mediated nanoparticle.

Therefore, the green synthesis method using biological specimens has emerged as a simple, economical and environmentally friendly. Of the biological methods of nanoparticles synthesis, the techniques based on using 
plant parts have been widely reported [45-48]. The green approach is the preferred method for metal and metal oxide nanoparticles synthesis because of its feasibility, low toxicity, environmental friendliness, and safety to human health when compared with physical and chemical methods. In recent times, plant mediated nanoparticle synthesis using plant part extract or living plant has been reported in literatures [49,50]. Fresh or dried plant materials; leaf, fruit, bark, seed, peel, and root extracts perform well in the green synthesis of plant mediated nanoparticles under normal experimental conditions [46, 51-56] and replacing hazardous chemicals by plant phytochemicals.

Several applications of bio synthesized metal nanoparticles for wastewater treatment have including, silver nanoparticle [57], iron oxide nanoparticle [58$60]$, and zinc oxide nanoparticle $[61,62]$ have been reported.

\section{Plant as source of bioactive materials for metallic nanoparticles}

Application of the biological systems such as plants and microorganisms has found as an alternative procedure for preparation of nanoparticles [63-65]. Biosynthesis method of nanoparticles has provided a great help to overcome some drawbacks, such as high energy and space requirement as well as high cost associated with physical and chemical methods $[59,66$, 67]. More importantly, the biosynthesized nanoparticles are free of hazardous material on the surface nano-sized materials. Biosynthesis of NPs are eco-friendly, time affordable, and cost effective [68]. The utilization of plant materials in the synthesis of nanoparticles engages the secondary metabolites such as alkaloids, flavonoids, saponins, phenols, proteins, carbohydrates, glycosides, quinine, steroids, and tannins [69,70]. Biological agents act as reducers and/or stabilizers in the process of forming nanoparticles [71]. Although the exact mechanism involved in nanoparticles biosynthesis using extracts of various plants is ambiguous, it has been reported that the biomolecules in plant extract such as phenol, protein, and flavonoids play important roles in the reduction of metal ions and capping the biosynthesized nanoparticles [72]. The biosynthesis of plant mediated iron nanoparticles have been carried out by many researchers using a number of plants. Extracts of Neem leaves [58], Tangerine peel [60], Acacia nilotica pods [73], Albizia lebbeck leaves [74], L.camara fruit [75]; Eriobotrya japonica leaves [56]; orange peel [15]; Mangifera indica [76], Murraya Koenigii [76], Oolong tea [77], Zanthoxylum armatum leaves [78], green tea leaves [44, 79], Eucalyptus leaves [45], and Lantana camara leaves [80].

\section{Characterization of Iron Nanoparticles}

Identification and evaluation of the physical and chemical properties of nanomaterials are as important as their synthesis. Nanoparticles properties dictate their reactions and applications providing an opportunity to engineer materials for desired unique properties.

Table 1. Characterization techniques for nanoparticle properties.

\begin{tabular}{|c|c|c|c|c|}
\hline Entry & Parameters & Importance & Techniques & Ref. \\
\hline 1 & $\begin{array}{l}\text { Size and } \\
\text { dispersion }\end{array}$ & $\begin{array}{c}\text { Size reveals the external dimensions of a } \\
\text { particle while dispersion gives the degree to } \\
\text { which particles clump together into weakly } \\
\text { bound agglomerates or strongly bound } \\
\text { aggregates }\end{array}$ & $\begin{array}{l}\text { SEM, AFM, XRD, DLS, } \\
\text { and Back-calculation } \\
\text { from surface area } \\
\text { measurements }\end{array}$ & {$[81],[82]$} \\
\hline 2 & Shape & $\begin{array}{l}\text { Material shape as well as its surface } \\
\text { topography with the presence of ridges, cracks } \\
\text { or pores defines its morphology. It influences } \\
\text { dispersion, functionality and toxicity. }\end{array}$ & TEM, SEM, AFM & [83], [81] \\
\hline 3 & $\begin{array}{l}\text { Surface area, } \\
\text { charge and } \\
\text { chemistry }\end{array}$ & $\begin{array}{l}\text { Surface properties influence reactivity and } \\
\text { surface interactions with ligands. }\end{array}$ & $\begin{array}{l}\text { Adsorption of gases, } \\
\text { BET, EMA, AES }\end{array}$ & [84] \\
\hline 4 & $\begin{array}{l}\text { Chemical } \\
\text { composition and } \\
\text { crystal structure }\end{array}$ & $\begin{array}{l}\text { Chemical composition reveals the atomic } \\
\text { elements which a nanoparticle is composed. } \\
\text { Crystal structure determination reveals the } \\
\text { arrangement of nano structure which could be } \\
\text { crystal, amorphous or intermediate between } \\
\text { the two. Crystal structure influences physical } \\
\text { and chemical properties. }\end{array}$ & $\begin{array}{l}\text { AAS, ICPMS, NAA, } \\
\text { XRD, XRAS, XRF, } \\
\text { XRAS, EDX }\end{array}$ & [85], [82] \\
\hline 5 & Solubility & $\begin{array}{l}\text { This is done to measure the degree to which } \\
\text { materials dissolve from a nanoparticle. }\end{array}$ & AAS, ICPMS & {$[86]$} \\
\hline
\end{tabular}


Table 2. Plant-Iron nanoparticles, size, morphology and applications.

\begin{tabular}{|c|c|c|c|c|c|c|}
\hline Entry & Plant & $\begin{array}{l}\text { Size } \\
(\mathbf{n m})\end{array}$ & Morphology & Adsorbate & $\begin{array}{l}\text { Adsorption capacity (mg/g) } \\
\text { / Percentage efficiency }(\%)\end{array}$ & Ref. \\
\hline 1 & Neem leaf & 21.03 & Spherical & DDT & $--/ 90.20$ & [58] \\
\hline 2 & Tangerine peel & $50-20$ & Spherical & $\mathrm{Cd}$ & $10.90 / 90.00$ & [60] \\
\hline 3 & Eriobotrya japonica & 89.00 & Spherical & $\mathrm{Cr}(\mathrm{VI})$ & $312.5 /--$ & [91] \\
\hline 4 & Acacia nilotica pods & 230 & Irregular & Methyl Orange & 19/-- & [73] \\
\hline 5 & Albizia lebbeck leaf & -- & -- & Crystal violet & $--/ 96.59$ & [74] \\
\hline 6 & Albizia lebbeck leaf & -- & -- & Congo red & $--/ 96.59$ & [74] \\
\hline 7 & L.camara fruit & 1.9 & Spherical & $\mathrm{Ni}$ (II) & 227.20/-- & {$[75]$} \\
\hline 8 & $\begin{array}{c}\text { Eriobotrya japonica } \\
\text { leaf }\end{array}$ & 171.2 & Irregular spherical & Basic Red 46 & & [56] \\
\hline 9 & Orange peel & 500 & Spherical & $\mathrm{Cd}$ & $--/ 71.43$ & {$[3]$} \\
\hline 10 & Mangifera indica & $100-150$ & Spherical & $\begin{array}{c}\text { Total } \\
\text { phosphates }\end{array}$ & $--/ 91.89$ & [76] \\
\hline 11 & Murraya Koenigii & $100-150$ & Spherical & Phosphates & $--/ 97.68$ & [76] \\
\hline 12 & Murraya Koenigii & $100-150$ & Spherical & $\begin{array}{l}\text { Ammonia } \\
\text { nitrogen }\end{array}$ & $--/ 87.08$ & {$[76]$} \\
\hline 13 & Murraya Koenigii & $100-150$ & Spherical & COD & $--/ 88.24$ & {$[76]$} \\
\hline 14 & Azadirachta Indica & $96-110$ & Spherical & Phosphates & $--/ 98.08$ & {$[76]$} \\
\hline 15 & Azadirachta Indica & $96-110$ & Spherical & $\begin{array}{l}\text { Ammonia } \\
\text { nitrogen }\end{array}$ & $--/ 84.32$ & {$[76]$} \\
\hline 16 & Azadirachta Indica & $96-110$ & Spherical & COD & $--/ 82.35$ & {$[76]$} \\
\hline 17 & Magnolia Champaca & $99-129$ & Spherical & Phosphates & $--/ 98.84$ & {$[76]$} \\
\hline 18 & Magnolia Champaca & $99-129$ & Spherical & $\begin{array}{l}\text { Ammonia } \\
\text { nitrogen }\end{array}$ & $--/ 74.78$ & [76] \\
\hline 19 & Magnolia Champaca & $99-129$ & Spherical & COD & $--/ 88.23$ & [76] \\
\hline 20 & Magnolia Champaca & $99-129$ & Spherical & BOD & $--/ 88.23$ & {$[76]$} \\
\hline 21 & Oolong tea extract & $40-50$ & Spherical & Malachite green & $--/ 75.5$ & [77] \\
\hline 22 & $\begin{array}{l}\text { Zanthoxylum } \\
\text { armatum leaf }\end{array}$ & 17 & Spherical & Methylene blue & $0.4712 /--$ & {$[78]$} \\
\hline 23 & Green tea leaf & $5-15$ & Spherical & $\begin{array}{l}\text { Degradation of } \\
\text { bromothymol } \\
\text { blue }\end{array}$ & Effective & [79] \\
\hline 24 & Green tea leaf & $40-60$ & Irregular clusters & Methylene blue & $--/ 99$ & {$[44]$} \\
\hline 25 & Green tea leaf & $40-60$ & Irregular clusters & Methyl orange & $--/ 99$ & [44] \\
\hline 26 & $\begin{array}{c}\text { Eucalyptus leaf } \\
\text { extract }\end{array}$ & $20-80$ & Spherical & Total N & $--/ 71.7$ & {$[45]$} \\
\hline 27 & $\begin{array}{c}\text { Eucalyptus leaf } \\
\text { extract }\end{array}$ & $20-80$ & Spherical & COD & $--/ 84.5$ & [45] \\
\hline
\end{tabular}


This makes their characterization a crucial step to fully understand the origin of nanoparticle behaviour, and subsequently translate their laboratory performances to specific real word applications. To fully comprehend the features of nanoparticles, investigations are necessary on particle size and distributions, particle shape, chemical composition and crystal structure, surface area, surface chemistry and charge and solubility. The investigations can be conducted given the large number of existing techniques, including the combination of different methods and different approaches to data analysis for a same technique. Some parameters, characterization techniques, and their importance are presented in Table 1.

\section{Iron Nanoparticles}

Iron nanoparticles are the iron oxide particles with diameters $\leq 100 \mathrm{~nm}$. Iron oxide nanoparticles consist of maghemite $\left(\gamma-\mathrm{Fe}_{2} \mathrm{O}_{3}\right)$ and/or magnetite $\left(\mathrm{Fe}_{3} \mathrm{O}_{4}\right)$ particles. $\mathrm{Fe}_{3} \mathrm{O}_{4}$ and $\gamma-\mathrm{Fe}_{2} \mathrm{O}_{3}$ display ferromagnetic behaviour and both crystallize in the inverse spinel cubic structure [87-90]. The major difference between the two structures is the presence of $\mathrm{Fe}^{2+}$ and $\mathrm{Fe}^{3+}$ ions in $\mathrm{Fe}_{3} \mathrm{O}_{4}$, while $\gamma-\mathrm{Fe}_{2} \mathrm{O}_{3}$ contains only $\mathrm{Fe}^{3+}$ ions and vacancies in their sub-lattices [87]. Also, while the temperature above which a material loses its magnetic properties known as Curie temperature (TC) is $900 \mathrm{~K}$ for maghemite, magnetite has a Curie temperature (TC) of 860 K [88-90]. Recently, iron oxide nanoparticles have attracted much interest due to their unique properties including, superparamagnetism, surface-tovolume ratio, greater surface area, and easy separation methodology. Iron oxide nanoparticles have great potential for their applications as wastewater treatment adsorbents, catalytic materials, pigments, gas sensors, coatings, ion exchangers, magnetic data storage devices, magnetic recording devices, magnetic resonance imaging, and bioseparation [87].

It is a well-established fact that iron and iron oxide nanoparticles show greater catalytic activities for dye reduction and removal. Recently, there has been a great interest in using the plant extract in synthesizing the metal nanoparticles such as iron, silver, gold, magnesium, and platinum for industrial applications. The iron oxide nanoparticle is safer and cheaper. Iron oxide nanoparticles have been synthesized using biological methods. These include the use of extract of different plants. Table 2 contains some reports of earlier research works.

\section{Justification of using Nanoparticles}

The iron nanoparticles can be produced by one of the cheapest, simplest and most effective method [92]. Nanosized iron oxides are potential materials for efficient binding metal ions in water and wastewater treatment. Its small size gives a high surface-area-tovolume ratio that allows good interaction with various chemical species, both aqueous and gaseous [93]. Material manipulation such as changing the shape and size of iron oxide during activation expose the materials' most active catalytic sites, thereby making it an efficient and cheaper catalyst for various reactions [92,94-96]. Also, adjustment of iron oxide compositions can be made for the selective adsorption of different metal ions. Iron oxide nanoparticles are now seen to be attractive for the adsorption or recovery of metal ions from the natural water streams or industrial wastes [97].

\section{Conclusion}

This review discussed the recent growing interest in the use of plant mediated iron nanoparticles for water and wastewater treatment. Various cost effective and environmentally friendly green synthesis techniques have been developed using biological specimens and taking over from the well-known physical and chemical methods of nano synthesis which are considered toxic and not cost-effective. With the continual deployment of nanosized iron oxide particles for environmental sustainability as environmental mediators, there is a need to search for suitable plants to sustain the goal without jeopardizing the existing functions of medicinal plants.

\section{Acknowledgment}

The authors wish to thank Mr. Owoeye Seun Samuel of the department of Glass \& Ceramics technology, for his contributions during the present work.

\section{Disclosure statement}

No potential conflict of interest was reported by the authors.

\section{References}

[1] Pathania, D., Sharma, S., \& Singh, P. (2017). Removal of methylene blue by adsorption onto activated carbon developed from Ficus carica bast. Arabian Journal of Chemistry, 10, S1445S1451.

[2] Auta, M., \& Hameed, B. H. (2011). Preparation of waste tea activated carbon using potassium acetate as an activating agent for adsorption of Acid Blue 25 dye. Chemical Engineering Journal, 171(2), 502-509.

[3] Gupta, V. K., Jain, R., Mittal, A., Saleh, T. A., Nayak, A., Agarwal, S., \& Sikarwar, S. (2012). Photo-catalytic degradation of toxic dye amaranth 
on $\mathrm{TiO} 2 / \mathrm{UV}$ in aqueous suspensions. Materials Science and Engineering: C, 32(1), 12-17.

[4] Gouamid, M., Ouahrani, M. R., \& Bensaci, M. B. (2013). Adsorption equilibrium, kinetics and thermodynamics of methylene blue from aqueous solutions using date palm leaves. Energy procedia, 36, 898-907.

[5] Robinson, T., McMullan, G., Marchant, R., \& Nigam, P. (2001). Remediation of dyes in textile effluent: a critical review on current treatment technologies with a proposed alternative. Bioresource technology, 77(3), 247255.

[6] Abegunde, S. M., Adejuwon, O. M., \& Olorunfemi, T. O. (2017). Safety assessment of hand-dug well water samples from selected towns in Ekiti State, Nigeria. Journal of Advanced Research In Applied Chemistry \& Chemical Engineering, 4(1\&2), 4045.

[7] Abegunde, S. M., Akinyele, S. A., \& Awonyemi, I. O. (2018). Effect of cassava whey on the physicochemical parameters and heavy metals distribution in soil. Turkish Journal of Agriculture-Food Science and Technology, 6(9), 1196-1199.

[8] Bello, O. S., Adegoke, K. A., \& Akinyunni, O. O. (2017). Preparation and characterization of a novel adsorbent from Moringa oleifera leaf. Applied Water Science, 7(3), 1295-1305.

[9] Banerjee, S., \& Chattopadhyaya, M. C. (2017). Adsorption characteristics for the removal of a toxic dye, tartrazine from aqueous solutions by a low cost agricultural by-product. Arabian Journal of Chemistry, 10, S1629-S1638.

[10] Hameed, K. S., Muthirulan, P., \& Sundaram, M. M. (2017). Adsorption of chromotrope dye onto activated carbons obtained from the seeds of various plants: equilibrium and kinetics studies. Arabian Journal of Chemistry, 10, S2225$\mathrm{S} 2233$.

[11] Hajati, S., Ghaedi, M., Karimi, F., Barazesh, B., Sahraei, R., \& Daneshfar, A. (2014). Competitive adsorption of Direct Yellow 12 and Reactive Orange 12 on $\mathrm{ZnS}$ : Mn nanoparticles loaded on activated carbon as novel adsorbent. Journal of Industrial and Engineering Chemistry, 20(2), 564571.

[12] Abegunde, S. M., Oyebanji, A. O., \& Osibanjo, O. (2018). Evaluation of Digestion Procedures on Heavy Metals in Soil of a Dumpsite in Ibadan, South-western Nigeria. Suan Sunandha Science and Technology Journal, 5(2), 1-5.

[13] Behnajady, M. A., Modirshahla, N., \& Ghanbary, F. (2007). A kinetic model for the decolorization of CI Acid Yellow 23 by Fenton process. Journal of Hazardous Materials, 148(1-2), 98-102.
[14] Saravanan, R., Sacari, E., Gracia, F., Khan, M. M., Mosquera, E., \& Gupta, V. K. (2016). Conducting PANI stimulated $\mathrm{ZnO}$ system for visible light photocatalytic degradation of coloured dyes. Journal of molecular liquids, 221, 1029-1033.

[15] Gupta, V. K., \& Nayak, A. (2012). Cadmium removal and recovery from aqueous solutions by novel adsorbents prepared from orange peel and Fe2O3 nanoparticles. Chemical Engineering Journal, 180, 81-90.

[16] Gupta, V. K., Jain, R., Nayak, A., Agarwal, S., \& Shrivastava, M. (2011). Removal of the hazardous dye - tartrazine by photodegradation on titanium dioxide surface. Materials Science and Engineering: C, 31(5), 1062-1067.

[17] Saleh, T. A., \& Gupta, V. K. (2012). Column with CNT/magnesium oxide composite for lead (II) removal from water. Environmental Science and Pollution Research, 19(4), 1224-1228.

[18] Saravanan, R., Gracia, F., Khan, M. M., Poornima, V., Gupta, V. K., Narayanan, V., \& Stephen, A. (2015). $\mathrm{ZnO} / \mathrm{CdO}$ nanocomposites for textile effluent degradation and electrochemical detection. Journal of molecular liquids, 209, 374380.

[19] Saravanan, R., Gupta, V. K., Mosquera, E., \& Gracia, F. (2014). Preparation and characterization of $\mathrm{V} 2 \mathrm{O} / \mathrm{ZnO}$ nanocomposite system for photocatalytic application. Journal of Molecular Liquids, 198, 409-412.

[20] Abbasi, M., \& Asl, N. R. (2008). Sonochemical degradation of Basic Blue 41 dye assisted by nanoTiO2 and $\mathrm{H} 2 \mathrm{O} 2$. Journal of hazardous materials, 153(3), 942-947.

[21] García-Montaño, J., Ruiz, N., Munoz, I., Domenech, X., García-Hortal, J. A., Torrades, F., \& Peral, J. (2006). Environmental assessment of different photo-Fenton approaches for commercial reactive dye removal. Journal of hazardous materials, 138(2), 218-225.

[22] Saleh, T. A., \& Gupta, V. K. (2012). Photocatalyzed degradation of hazardous dye methyl orange by use of a composite catalyst consisting of multi-walled carbon nanotubes and titanium dioxide. Journal of colloid and interface science, 371(1), 101-106.

[23] Lorenc-Grabowska, E., \& Gryglewicz, G. (2007). Adsorption characteristics of Congo Red on coalbased mesoporous activated carbon. Dyes and pigments, 74(1), 34-40.

[24] Malik, P. K., \& Sanyal, S. K. (2004). Kinetics of decolourisation of azo dyes in wastewater by UV/H2O2 process. Separation and Purification Technology, 36(3), 167-175. 
[25] Banat, I. M., Nigam, P., Singh, D., \& Marchant, R. (1996). Microbial decolorization of textiledyecontaining effluents: a review. Bioresource technology, 58(3), 217-227.

[26] Malik, P. K., \& Saha, S. K. (2003). Oxidation of direct dyes with hydrogen peroxide using ferrous ion as catalyst. Separation and purification technology, 31(3), 241-250.

[27] Asfaram, A., Ghaedi, M., Hajati, S., Goudarzi, A., \& Dil, E. A. (2017). Screening and optimization of highly effective ultrasound-assisted simultaneous adsorption of cationic dyes onto $\mathrm{Mn}$ doped Fe3O4-nanoparticle-loaded activated carbon. Ultrasonics sonochemistry, 34, 1-12.

[28] Dil, E. A., Ghaedi, M., Asfaram, A., Hajati, S., Mehrabi, F., \& Goudarzi, A. (2017). Preparation of nanomaterials for the ultrasound-enhanced removal of $\mathrm{Pb} 2+$ ions and malachite green dye: chemometric optimization and modeling. Ultrasonics Sonochemistry, 34, 677691.

[29] Ghaedi, M., Khafri, H. Z., Asfaram, A., \& Goudarzi, A. (2016). Response surface methodology approach for optimization of adsorption of Janus Green B from aqueous solution onto $\mathrm{ZnO} / \mathrm{Zn}(\mathrm{OH})$ 2-NP-AC: kinetic and isotherm study. Spectrochimica Acta Part A: Molecular and Biomolecular Spectroscopy, 152, 233-240.

[30] Mazaheri, H., Ghaedi, M., Asfaram, A., \& Hajati, S. (2016). Performance of $\mathrm{CuS}$ nanoparticle loaded on activated carbon in the adsorption of methylene blue and bromophenol blue dyes in binary aqueous solutions: using ultrasound power and optimization by central composite design. Journal of Molecular Liquids, 219, 667676.

[31] Mittal, A., Kaur, D., Malviya, A., Mittal, J., \& Gupta, V. K. (2009). Adsorption studies on the removal of coloring agent phenol red from wastewater using waste materials as adsorbents. Journal of colloid and interface science, 337(2), 345-354.

[32] Mittal, A., Mittal, J., Malviya, A., \& Gupta, V. K. (2009). Adsorptive removal of hazardous anionic dye "Congo red" from wastewater using waste materials and recovery by desorption. Journal of colloid and interface science, 340(1), 16-26.

[33] Jain, A. K., Gupta, V. K., Bhatnagar, A., \& Suhas. (2003). A comparative study of adsorbents prepared from industrial wastes for removal of dyes. Separation Science and Technology, 38(2), 463-481.

[34] Olasehinde, E. F. \& Abegunde S,. M. (2019). Preparation and characterization of a new adsorbent from raphia taedigera seed. Journal of
Research on Engineering Structures and Materials, $\quad$ doi:10.17515/resm2019.139ma0713 (online first)

[35] Slejko, F. L. (Ed.). (1985). Adsorption technology: a step-by-step approach to process evaluation and application (pp. 1-6). M. Dekker.

[36] Rosarin, F. S., \& Mirunalini, S. (2011). Nobel metallic nanoparticles with novel biomedical properties. J Bioanal Biomed, 3(4), 085-091.

[37] Prabhu, S., \& Poulose, E. K. (2012). Silver nanoparticles: mechanism of antimicrobial action, synthesis, medical applications, and toxicity effects. International nano letters, 2(1), 32.

[38] Albrecht, M. A., Evans, C. W., \& Raston, C. L. (2006). Green chemistry and the health implications of nanoparticles. Green chemistry, 8(5), 417-432.

[39] Khalil, K. A., Fouad, H., Elsarnagawy, T., \& Almajhdi, F. N. (2013). Preparation and characterization of electrospun PLGA/silver composite nanofibers for biomedical applications. Int J Electrochem Sci, 8(3), 34833493.

[40] Athar, M., \& Das, A. J. (2014). Therapeutic nanoparticles: State-of-the-art of nanomedicine. Advanced Material Reviews, 1(1), 25-37.

[41] Meyer, A., Eskandari, S., Grallath, S., \& Rentsch, D. (2006). AtGAT1, a high affinity transporter for $\gamma$-aminobutyric acid in Arabidopsis thaliana. Journal of biological chemistry, 281(11), 7197-7204.

[42] Mukherjee, P., Ahmad, A., Mandal, D., Senapati, S., Sainkar, S. R., Khan, M. I., ... \& Sastry, M. (2001). Bioreduction of AuCl4- ions by the fungus, Verticillium sp. and surface trapping of the gold nanoparticles formed. Angewandte Chemie International Edition, 40(19), 3585-3588.

[43] Thakkar, K. N., Mhatre, S. S., \& Parikh, R. Y. (2010). Biological synthesis of metallic nanoparticles. Nanomedicine: nanotechnology, biology and medicine, 6(2), 257-262.

[44] Shahwan, T., Sirriah, S. A., Nairat, M., Boyac1, E., Eroğlu, A. E., Scott, T. B., \& Hallam, K. R. (2011). Green synthesis of iron nanoparticles and their application as a Fenton-like catalyst for the degradation of aqueous cationic and anionic dyes. Chemical Engineering Journal, 172(1), 258266.

[45] Wang, T., Jin, X., Chen, Z., Megharaj, M., \& Naidu, R. (2014). Green synthesis of $\mathrm{Fe}$ nanoparticles using eucalyptus leaf extracts for treatment of eutrophic wastewater. Science of the total environment, 466, 210-213.

[46] Kumar, B., Smita, K., Cumbal, L., \& Debut, A. (2014). Synthesis of silver nanoparticles using 
Sacha inchi (Plukenetia volubilis L.) leaf extracts. Saudi journal of biological sciences, 21(6), 605-609.

[47] Machado, S., Pinto, S. L., Grosso, J. P., Nouws, H. P. A., Albergaria, J. T., \& Delerue-Matos, C. (2013). Green production of zero-valent iron nanoparticles using tree leaf extracts. Science of the Total Environment, 445, 1-8.

[48] Smuleac, V., Varma, R., Sikdar, S., \& Bhattacharyya, D. (2011). Green synthesis of Fe and $\mathrm{Fe} / \mathrm{Pd}$ bimetallic nanoparticles in membranes for reductive degradation of chlorinated organics. Journal of membrane science, 379(1-2), 131-137.

[49] Gardea-Torresdey, J. L., Gomez, E., PeraltaVidea, J. R., Parsons, J. G., Troiani, H., \& JoseYacaman, M. (2003). Alfalfa sprouts: a natural source for the synthesis of silver nanoparticles. Langmuir, 19(4), 1357-1361.

[50] Park, S., Kim, W., Tian, G., Gygi, S. P., \& Finley, D. (2011). Structural defects in the regulatory particle-core particle interface of the proteasome induce a novel proteasome stress response. Journal of Biological Chemistry, 286(42), 36652-36666.

[51] Mehmood, A., Murtaza, G., Bhatti, T. M., Raffi, M., \& Kausar, R. (2014). Antibacterial efficacy of silver nanoparticles synthesized by a green method using bark extract of Melia azedarach L. Journal of Pharmaceutical Innovation, 9(3), 238-245.

[52] Kumar, B., Angulo, Y., Smita, K., Cumbal, L., \& Debut, A. (2016). Capuli cherry-mediated green synthesis of silver nanoparticles under white solar and blue LED light. Particuology, 24, 123-128.

[53] Kumar, B., Smita, K., Cumbal, L., \& Angulo, Y. (2015). Fabrication of silver nanoplates using Nephelium lappaceum (Rambutan) peel: a sustainable approach. Journal of Molecular Liquids, 211, 476-480.

[54] Kumar, B., Smita, K., Cumbal, L., \& Debut, A. (2014). Sacha inchi (Plukenetia volubilis L.) oil for one pot synthesis of silver nanocatalyst: an ecofriendly approach. Industrial Crops and Products, 58, 238-243.

[55] Shameli, K., Ahmad, M. B., Zamanian, A., Sangpour, P., Shabanzadeh, P., Abdollahi, Y. \& Zarga,r M. (2012). Green biosynthesis of silver nanoparticles using Curcuma longa tuber powder. International journal of nanomedicine, 7, 56035610.

[56] Önal, E. S., Yatkin, T., Ergüt, M., \& Özer, A. (2017). Green synthesis of iron nanoparticles by aqueous extract of Eriobotrya japonica leaves as a heterogeneous fenton-like catalyst: degradation of basic red 46. Int J Chem Eng Appl, 8, 327-333.
[57] Abbasi, M., Saeed, F., \& Rafique, U. (2014). Preparation of silver nanoparticles from synthetic and natural sources: remediation model for PAHs. In IOP Conference Series: Materials Science and Engineering, 60(1), 012061.

[58] Bhupendra, P. \& Pooja, S. (2019). Adsorption Study of Green Synthesized Fe-Oxide Nanoparticle for DDT Removal. International Journal of Pharmaceutical Sciences Review and Research, 55(2), 84-90.

[59] Wei, X., Luo, M., Li, W., Yang, L., Liang, X., Xu, L., ... \& Liu, H. (2012). Synthesis of silver nanoparticles by solar irradiation of cell-free Bacillus amyloliquefaciens extracts and AgNO3. Bioresource technology, 103(1), 273278.

[60] Ehrampoush, M. H., Miria, M., Salmani, M. H., \& Mahvi, A. H. (2015). Cadmium removal from aqueous solution by green synthesis iron oxide nanoparticles with tangerine peel extract. Journal of Environmental Health Science and Engineering, 13(1), 84.

[61] Ghaedi, M., Ansari, A., Habibi, M. H., \& Asghari, A. R. (2014). Removal of malachite green from aqueous solution by zinc oxide nanoparticle loaded on activated carbon: kinetics and isotherm study. Journal of Industrial and Engineering Chemistry, 20(1), 17-28.

[62] Madiha, B., Zahid. Q.\& Aliya, B. (2018). Removal of Melachite Green Dye by Using Zinc Oxide Prepared by The Green Synthesis by Using Camellia Sinensis (Green Tea) Leafs Extract. Archives of Nanomedicine: Open Access Journal, 1(4), 000120.

[63] Naik, R. R., Stringer, S. J., Agarwal, G., Jones, S. E. \& Stone, M. O. (2002). Biomimetic synthesis and patterning of silver nanoparticles. Nature Materials, 1(3), 169-172.

[64] Fayaz, A. M., Balaji, K., Girilal, M., Yadav, R., Kalaichelvan, P. T., \& Venketesan, R. (2010). Biogenic synthesis of silver nanoparticles and their synergistic effect with antibiotics: a study against gram-positive and gram-negative bacteria. Nanomedicine: Nanotechnology, Biology and Medicine, 6(1), 103-109.

[65] Singhal, G., Bhavesh, R., Kasariya, K., Sharma, A. R., \& Singh, R. P. (2011). Biosynthesis of silver nanoparticles using Ocimum sanctum (Tulsi) leaf extract and screening its antimicrobial activity. Journal of Nanoparticle Research, 13(7), 2981-2988.

[66] Gade, A. K., Bonde, P., Ingle, A. P., Marcato, P. D., Duran, N., \& Rai, M. K. (2008). Exploitation of Aspergillus niger for synthesis of silver nanoparticles. Journal of Biobased Materials and Bioenergy, 2(3), 243-247. 
[67] Ouda, S. M. (2014). Antifungal activity of silver and copper nanoparticles on two plant pathogens, Alternaria alternata and Botrytis cinerea. Research Journal of Microbiology, 9(1), 34-42.

[68] Pirtarighat, S., Ghannadnia, M., \& Baghshahi, S. (2019). Green synthesis of silver nanoparticles using the plant extract of Salvia spinosa grown in vitro and their antibacterial activity assessment. Journal of Nanostructure in Chemistry, 9(1), 1-9.

[69] Jirovetz, L., Buchbauer, G., Shafi, M. P., \& Leela, N. K. (2003). Analysis of the essential oils of the leaves, stems, rhizomes and roots of the medicinal plant Alpinia galanga from southern India. ACTA PHARMACEUTICA-ZAGREB-, 53(2), 73-82.

[70] Abegunde, S. M. (2018). Proximate composition, phytochemical analysis and elemental characterization of Raphia taedigera Seed. Asian Journal of Chemical Sciences, 1-8.

[71] Chandran, S. P., Chaudhary, M., Pasricha, R., Ahmad, A., \& Sastry, M. (2006). Synthesis of gold nanotriangles and silver nanoparticles using Aloevera plant extract. Biotechnology progress, 22(2), 577-583.

[72] Krishnaraj, C., Jagan, E. G., Rajasekar, S., Selvakumar, P., Kalaichelvan, P. T., \& Mohan, N. J. C. S. B. B. (2010). Synthesis of silver nanoparticles using Acalypha indica leaf extracts and its antibacterial activity against water borne pathogens. Colloids and Surfaces B: Biointerfaces, 76(1), 50-56.

[73] Da'na, E., Taha, A., \& Afkar, E. (2018). Green synthesis of iron nanoparticles by acacia nilotica pods extract and its catalytic, adsorption, and antibacterial activities. Applied Sciences, 8(10), 1922.

[74] Raju, C. A. I., Bharadwaj, M. S., Prem, K., \& Satyanandam, K. (2016). Green synthesis of iron nanoparticles using Albizia lebbeck leaves for synthetic dyes decolorization. Int. J. Sci. Eng. Technol. Res, 5(12), 3429-3434.

[75] Nithya, K., Sathish, A., Kumar, P. S., \& Ramachandran, T. (2018). Fast kinetics and high adsorption capacity of green extract capped superparamagnetic iron oxide nanoparticles for the adsorption of $\mathrm{Ni}$ (II) ions. Journal of industrial and engineering chemistry, 59, 230-241.

[76] Devatha, C. P., Thalla, A. K., \& Katte, S. Y. (2016). Green synthesis of iron nanoparticles using different leaf extracts for treatment of domestic waste water. Journal of cleaner production, 139, 1425-1435.

[77] Huang, L., Weng, X., Chen, Z., Megharaj, M., \& Naidu, R. (2014). Synthesis of iron-based nanoparticles using oolong tea extract for the degradation of malachite green. Spectrochimica
Acta Part A: Molecular and Biomolecular Spectroscopy, 117, 801-804.

[78] Ramesh, A. V., Rama Devi, D., Mohan Botsa, S., \& Basavaiah, K. (2018). Facile green synthesis of $\mathrm{Fe} 3 \mathrm{O} 4$ nanoparticles using aqueous leaf extract of Zanthoxylum armatum DC. for efficient adsorption of methylene blue. Journal of Asian Ceramic Societies, 6(2), 145-155.

[79] Hoag, G. H., Collins, J. B., Holcomb, J. L., Hoag, J. R., Nadagouda, M. N. \& Varma, R. S. (2009). Degradation of bromothymol blue by greener nano-scale zero-valent iron synthesized using tea polyphenols. Journal of Materials Chemistry, 19(45), 8671-8677.

[80] Zielinsk,a A., Skwarek, E. \& Zaleska, A. (2019). Synthesis of Silver Nanoparticles Using Aqueous Extract of Medicinal Plants (Impatiens balsamina and Lantana camara) Fresh Leaves and Analysis of Antimicrobial Activity. International Journal of Microbiology. 2019, 1-8.

[81] Stefaniak, A. B. (2017). Principal Metrics and Instrumentation for Characterization of Engineered Nanomaterials. In Mansfield, Elisabeth; Kaiser, Debra L.; Fujita, Daisuke; Van de Voorde, Marcel (eds.). Metrology and Standardization of Nanotechnology, Wiley-VCH Verlag. 2017, 151-174.

[82] Hassellöv, M., Readman, J. W., Ranville, J. F. \& Tiede, K. (2008). Nanoparticle analysis and characterization methodologies in environmental risk assessment of engineered nanoparticles. Ecotoxicology, 17(5), 344-61.

[83] Powers, K. W., Palazuelos, M., Moudgil, B. M. \& Roberts, S. M. (2007). Characterization of the size, shape, and state of dispersion of nanoparticles for toxicological studies. Nanotoxicology. 1, 42-51.

[84] Powers, K. W., Brown, S. C., Krishna, V. B., Wasdo, S. C., Moudgil, B. M., \& Roberts, S. M. (2006). Research strategies for safety evaluation of nanomaterials. Part VI. Characterization of nanoscale particles for toxicological evaluation. Toxicological Sciences, 90(2), 296303.

[85] Akbari, B., Tavandashti, M. P., \& Zandrahimi, M. (2011). Particle size characterization of nanoparticles-a practicalapproach. Iranian Journal of Materials Science and Engineering, 8(2), 48-56.

[86] Klaessig, F., Marrapese, M. \& Abe, S. (2011). Nanotechnology Standards. Nanostructure Science and Technology. Springer, New York, NY, 2011, 21-52.

[87] Can, M. M., Coskun, M. \& Firat, T. (2012). A comparative study of nanosized iron oxide particles; magnetite $\left(\mathrm{Fe}_{3} \mathrm{O}_{4}\right)$, maghemite $\left(\mathrm{c}-\mathrm{Fe}_{2} \mathrm{O}_{3}\right)$ 
and hematite $\left(\mathrm{a}-\mathrm{Fe}_{2} \mathrm{O}_{3}\right)$, using ferromagnetic resonance, Journal of Alloys and Compounds, 542, 241-247.

[88] Belin, T., Guigue-Millot, N., Caillot, T., Aymes, D., \& Niepce, J. C. (2002). Influence of Grain Size, Oxygen Stoichiometry, and Synthesis Conditions on the g-Fe2O3 Vacancies Ordering and Lattice Parameters. Journal of Solid State Chemistry, 163(2), 459-465.

[89] Navrotsky, A., Mazeina, L., \& Majzlan, J. (2008). Size-driven structural and thermodynamic complexity in iron oxides. Science, 319(5870), 1635-1638.

[90] Morales, M. P., Serna, C. J., Bødker, F., \& Mørup, S. (1997). Spin canting due to structural disorder in maghemite. Journal of Physics: Condensed Matter, 9(25), 5461-5467.

[91] Onal, E. S., Tolga, Y. A., Memduh,a E. \& Ayla, O. (2019). Biosynthesis and Characterization of Iron Nanoparticles for Effective Adsorption of $\mathrm{Cr}(\mathrm{VI})$. International Journal of Chemical Engineering, 2019, 1-13.

[92] Mohapatra, M., \& Anand, S. (2010). Synthesis and applications of nano-structured iron oxides/hydroxides-a review. International Journal of Engineering, Science and Technology, 2(8).
[93] Hiemstra, T., Rahnemaie, R., \& van Riemsdijk, W. H. (2004). Surface complexation of carbonate on goethite: IR spectroscopy, structure and charge distribution. Journal of Colloid and Interface Science, 278(2), 282-290.

[94] Hasany, S. F., Ahmed, I., Rajan, J., \& Rehman, A. (2012). Systematic review of the preparation techniques of iron oxide magnetic nanoparticles. Nanosci. Nanotechnol, 2(6), 148158.

[95] LaMer, V. K., \& Dinegar, R. H. (1950). Theory, production and mechanism of formation of monodispersed hydrosols. Journal of the American Chemical Society, 72(11), 4847-4854.

[96] Lee, J. H., Huh, Y. M., Jun, Y. W., Seo, J. W., Jang, J. T., Song, H. T., ... \& Cheon, J. (2007). Artificially engineered magnetic nanoparticles for ultra-sensitive molecular imaging. Nature medicine, 13(1), 95-99.

[97] Rossi, L. M., Costa, N. J., Silva, F. P., \& Wojcieszak, R. (2014). Magnetic nanomaterials in catalysis: advanced catalysts for magnetic separation and beyond. Green Chemistry, 16(6), 2906-2933.

How to cite this manuscript: Segun Michael Abegunde, Kayode Solomon Idowu, Ayodele Omoniyi Sulaimon, Plant-Mediated Iron Nanoparticles and Their Applications as Adsorbents for Water Treatment-A Review, Journal of Chemical Reviews, 2020, 2(2), 103-113. 